\title{
Measurement of Organic Micropollutants in Rainwater as Indicators of Air Pollution in Onitsha, Anambra State, Nigeria
}

\author{
Sylvia Okonkwo $^{1^{*}}$ Ifeoma Okafor ${ }^{2} \quad$ Nnamdi Ofodum ${ }^{1}$ \\ 1.Department of Pure and Industrial Chemistry, Chukwuemeka Odumegwu Ojukwu University, P.M.B 02 \\ Uli, Anambra State, Nigeria \\ 2.Chemical Evaluation and Research Directorate, National Agency for Food and Drug Administration and \\ Control, Isolo, Lagos State Nigeria.
}

The research received no special grants

\section{Abstract}

Concentrations of persistent organic micro-pollutants were measured in rainwater collected in Onitsha city of Anambra State, Nigeria throughout the year 2012. Gas Chromatography-Mass Spectrometry (GC-MS) was used for analyzing Polycyclic Aromatic Hydrocarbons (PAHs) while Gas Chromatography with Micro Electron Capture Detector (GC/ $/ \mathrm{ECD})$ was used in the identification and quantification of Organochlorine Pesticides (OCPs) and Polychlorinated Biphenyls (PCBs). The chromatograms were evaluated by comparison with appropriate standards of known concentration. From the results, the mean concentrations of the PAHs in the rainwater samples range from $0.010 \mathrm{mg} / \mathrm{L}$ to $0.510 \mathrm{mg} / \mathrm{L}$, the mean concentrations of OCPs in the rainwater samples range from $0.002 \mathrm{mg} / \mathrm{L}$ to $0.040 \mathrm{mg} / \mathrm{L}$ while the mean concentration of PCBs in the rainwater samples ranges from $0.007 \mathrm{mg} / \mathrm{L}$ to $0.045 \mathrm{mg} / \mathrm{L}$. The concentration of these pollutants in the rainwater samples were above the maximum contaminant limit set by the United States Environmental Protection Agency (USEPA) for potable water and serves as markers of air pollution in Onitsha. The likelihood of exposure of residents to these toxic organic micropollutants through the breathing of air is plausible and requires urgent intervention to mitigate their adverse health effect.

Keywords: Environmental Pollution; Polycyclic Aromatic Hydrocarbons; Organochlorine Pesticides; Polychlorinated Biphenyls; Water Pollution; Air Pollution.

DOI: $10.7176 / \mathrm{JEES} / 9-6-09$

Publication date: June $30^{\text {th }} 2019$

\section{Introduction}

Pollution occurs when an environment becomes overloaded with a high concentration of harmful substances. These environmental pollutants are harmful to both human beings and other living things. Micro-organic pollutants are among the environmental pollutants which are known as Persistent Organic Pollutants (POPs) (Neff, 1984). They are toxic and some have been known to have an adverse effect on human health. However, this varies according to the type of pollutant, the level and length of exposure (Beyer et al., 2000).

Persistent organic pollutants are stable organic compounds which are resistant to environmental degradation through chemical, biological and photolytic processes (Ritter et al., 2007). They bioaccumulate in human and animal tissue, and also bio-magnify in food chains (Ritter et al., 2007). They are semi-volatile and this enables them to travel long distances in the air before deposition occurs (Ezemonye, 2003). POPs have been found on a global scale; in soil sediments, rainwater, snow in the fats of fish and terrestrial animal, as well as in human breast milk (Tanabe, 1988). The health effect related PCBs include liver, thyroid, dermal and ocular changes, reduced weight, reproductive toxicity and cancer (Bove et al., 1999).

No single, detailed, step by step analytical method can be recommended for analyzing POPs. Instead, Laboratories would use methods best suited to their situation and take part in international inter-laboratory comparison to verify their work (U.S.EPA, 2002). Some analytical instrument has been adopted by US-EPA in an effort to introduce flexibility in conducting environmental monitoring. Micro-organic POP pollutant has been determined in rainwater using rapid-phase microextraction method (Chanbasha et al., 2003). Solvent evaporation is generally used several times with all analytical method for PCBs/OCPs and PAHs determination.

Hence, this analysis was carried out to determine the concentration of the PAHs, OCPs and PCMs in the rainwater samples collected in Onitsha City. The results will be compared with international standards in $\mathrm{mg} / \mathrm{L}$ for drinking water in order to determine if it is within permissible limits. The results will also serve as markers for air pollutants in this city.

\section{MATERIAL/METHOD}

\subsection{Sample collection}

Samples of rainwater were collected from Iyiowa Oduekpe Fegge and Nkpor in all the months except for May and November 2012, the months for which the samples were not collected had little or no rainfall. The rainwater was collected manually with $10 \mathrm{~cm}$ glass funnel into 1 litre pre-cleaned glass bottles placed on a table 4 feet above the ground in the open air in the three locations of each city. They were collected on a weekly basis and refrigerated 
at $4^{0} \mathrm{C}$ to maintain the integrity of the sample. The composite samples of the weekly samples were made to have a monthly sample. It was the composite samples that were analyzed for PAHs, OCPs and PCBs.

\subsection{Sample preparation}

Organic micropollutants were extracted using $100 \mathrm{ml}$ of dichloromethane (DCM) solvent and the mixture was shaken. It was heated and separated. The blank samples were also prepared. The DCM was evaporated using a rotary evaporator equipped with a vacuum pump at $0.05 \mathrm{mmHg}$. The extract was then reconstituted with $1 \mathrm{ml}$ of hexane: acetone in the ratio of $4: 1$.

\subsection{Chromatographic analysis}

Modern Capillary Gas Chromatograph (GC) coupled to mass spectrometer was used to quantify polycyclic aromatic hydrocarbon while Gas Chromatograph with Electron Capture Detector was used for Organochlorine pesticides and Polychlorinated biphenyls. The Identification of the organic micropollutants was accomplished using external reference standards and relative retention time techniques, while quantification was achieved by comparing peak heights of the samples with corresponding peak heights of the reference standards of known concentrations.

\section{Result}

The result of the level of PAHs, OCPs and PCBs in rainwater samples collected in Onitsha are shown in the tables and figures below:

Table 1: The concentration of PAH Components $(\mathrm{mg} / \mathrm{L})$ in Rainwater Samples Collected in Onitsha

\begin{tabular}{|c|c|c|c|c|c|c|c|c|c|}
\hline 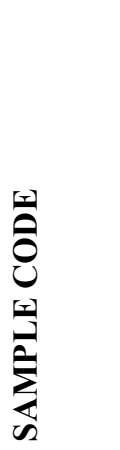 & 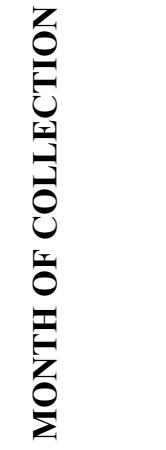 & 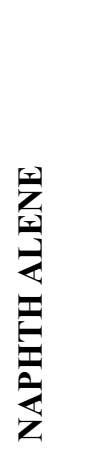 & 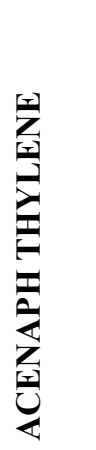 & 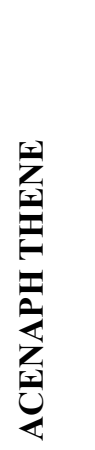 & 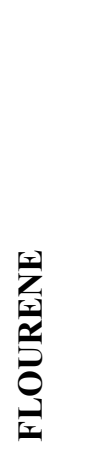 & 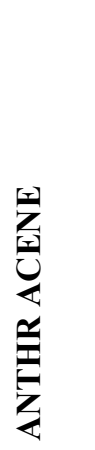 & 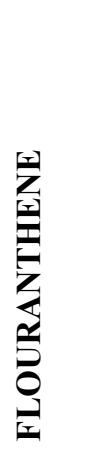 & 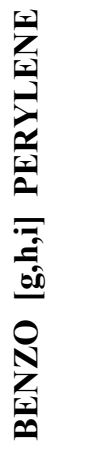 & 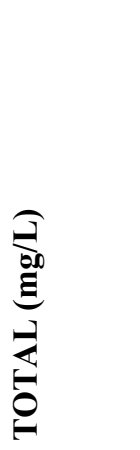 \\
\hline ON 1 & January & 0.010 & ND & ND & 0.018 & 0.007 & 0.006 & ND & 0.04 \\
\hline ON 2 & February & 0.013 & ND & ND & 0.032 & 0.012 & 0.013 & ND & 0.07 \\
\hline ON 3 & March & 0.021 & ND & ND & 0.048 & 0.011 & 0.010 & ND & 0.09 \\
\hline ON 4 & April & 0.035 & ND & ND & 0.031 & 0.010 & 0.011 & ND & 0.09 \\
\hline ON 5 & June & 0.017 & 0.510 & ND & 0.012 & 0.005 & 0.005 & ND & 0.55 \\
\hline ON 6 & July & 0.013 & ND & ND & 0.043 & 0.015 & 0.019 & ND & 0.09 \\
\hline ON 7 & August & 0.033 & ND & 0.011 & 0.068 & 0.018 & 0.016 & ND & 0.15 \\
\hline ON 8 & September & 0.010 & ND & ND & 0.031 & 0.010 & 0.021 & ND & 0.07 \\
\hline ON 9 & October & 0.007 & ND & ND & 0.021 & 0.008 & 0.007 & ND & 0.04 \\
\hline ON 10 & December & 0.007 & ND & ND & 0.023 & 0.008 & 0.011 & 0.011 & 0.06 \\
\hline \multirow[t]{2}{*}{ MEAN } & & 0.017 & 0.510 & 0.011 & 0.033 & 0.010 & 0.012 & 0.011 & 0.125 \\
\hline & & 0.001 & 0.000 & 0.000 & 0.007 & 0.004 & 0.005 & 0.000 & 0.009 \\
\hline
\end{tabular}

The following components of PAHs were not detected in the rainwater samples in Onitsha; PhenanthrenePyrene,Chrysene, Benzo[a]anthracene, Benzo[k]Flouranthene, Benzo[b] Fluoranthene, Dibenzo[a,h]anthracene and indeno[1,2,3 c-d] Pyrene.

Note: The months in which the PAHs were not detected are not included in the mean concentration. 


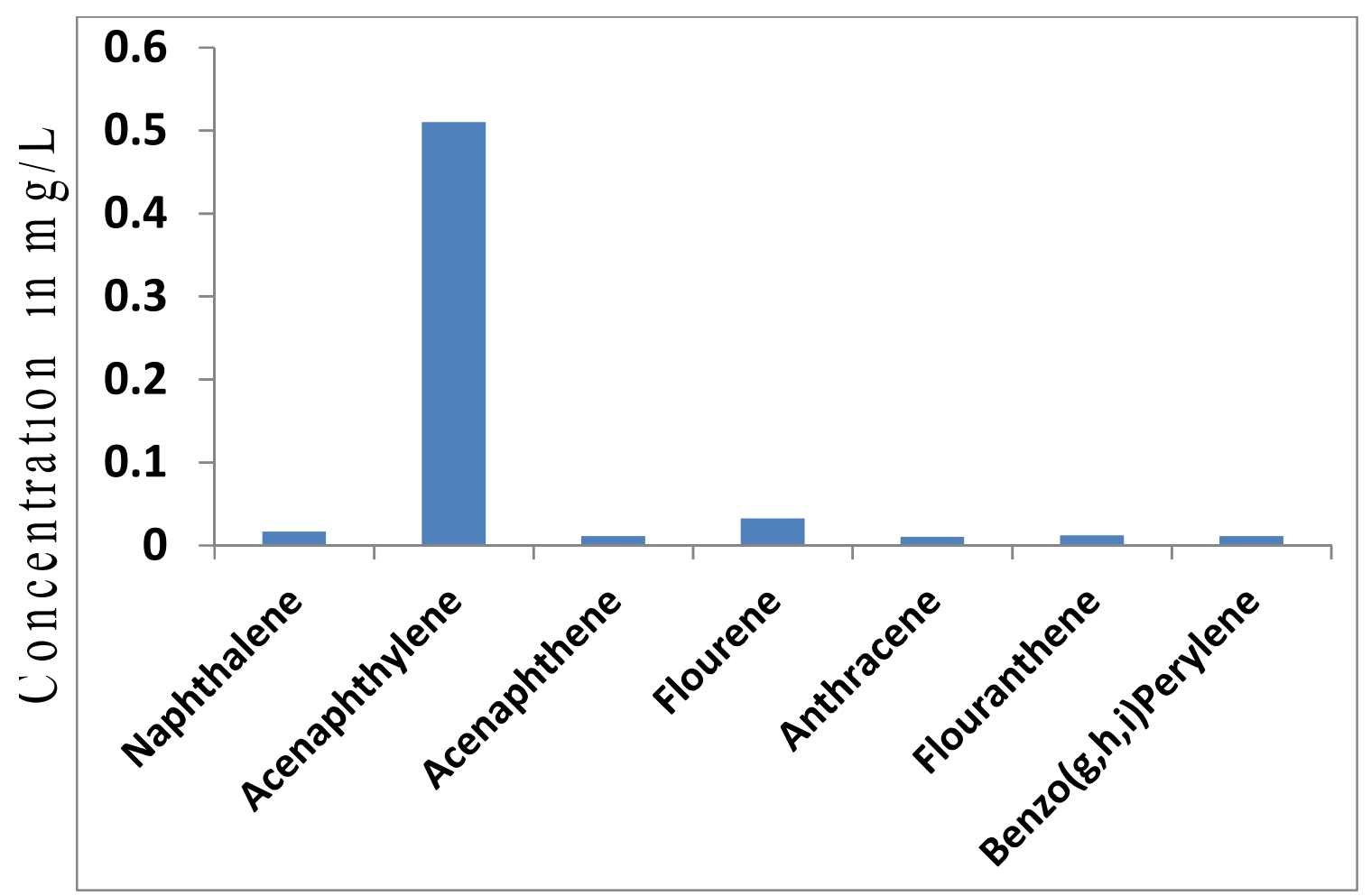

Fig. 1: Mean Concentrations of the PAHs (mg/L) in Rainwater Samples collected in Onitsha

Table 2: The concentration of OCPs Components ( $\mathrm{mg} / \mathrm{L})$ in Rainwater Samples Collected in Onitsha.

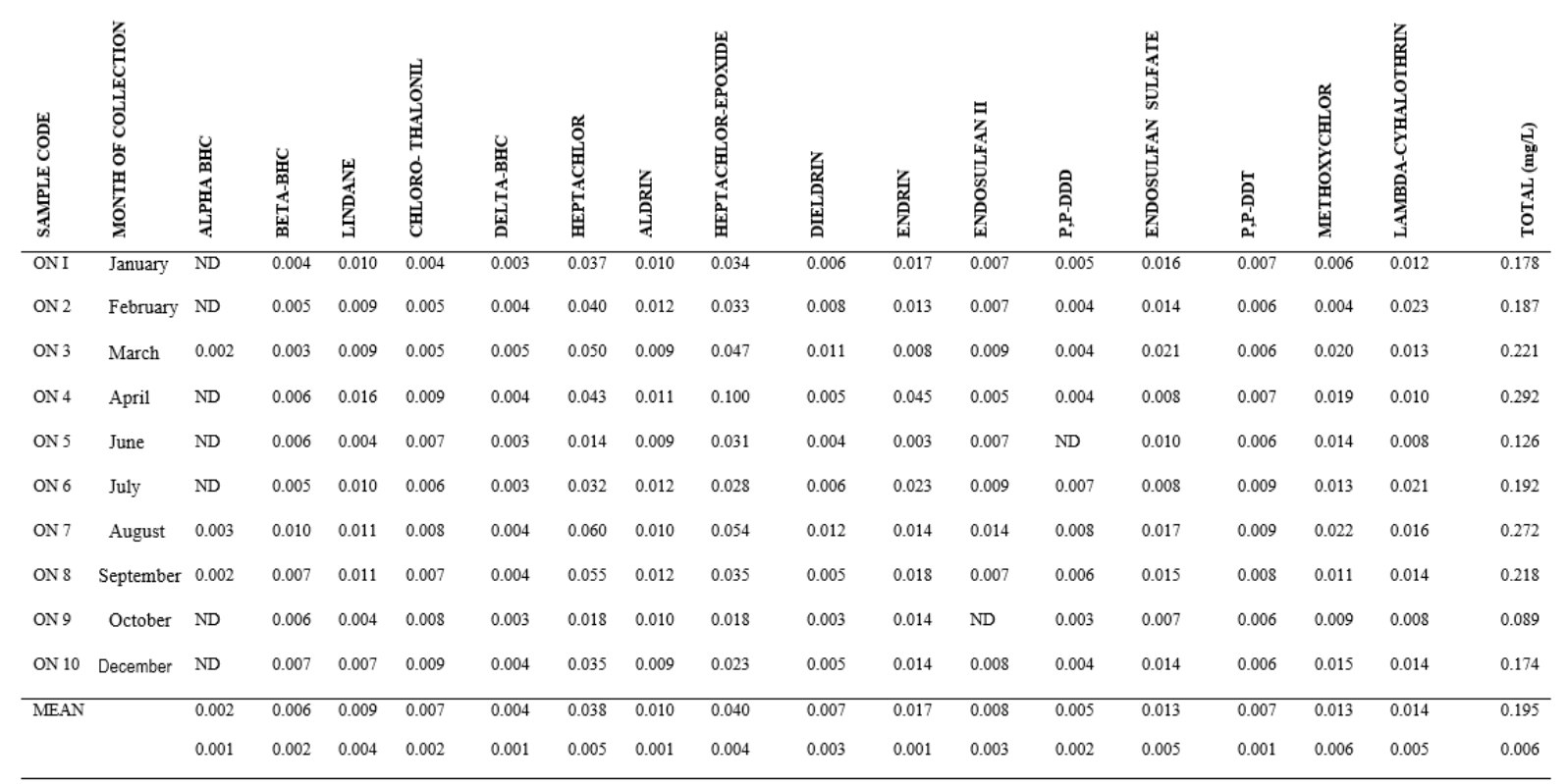

Note: The months in which the OCPs were not detected are not included in the mean concentration. 


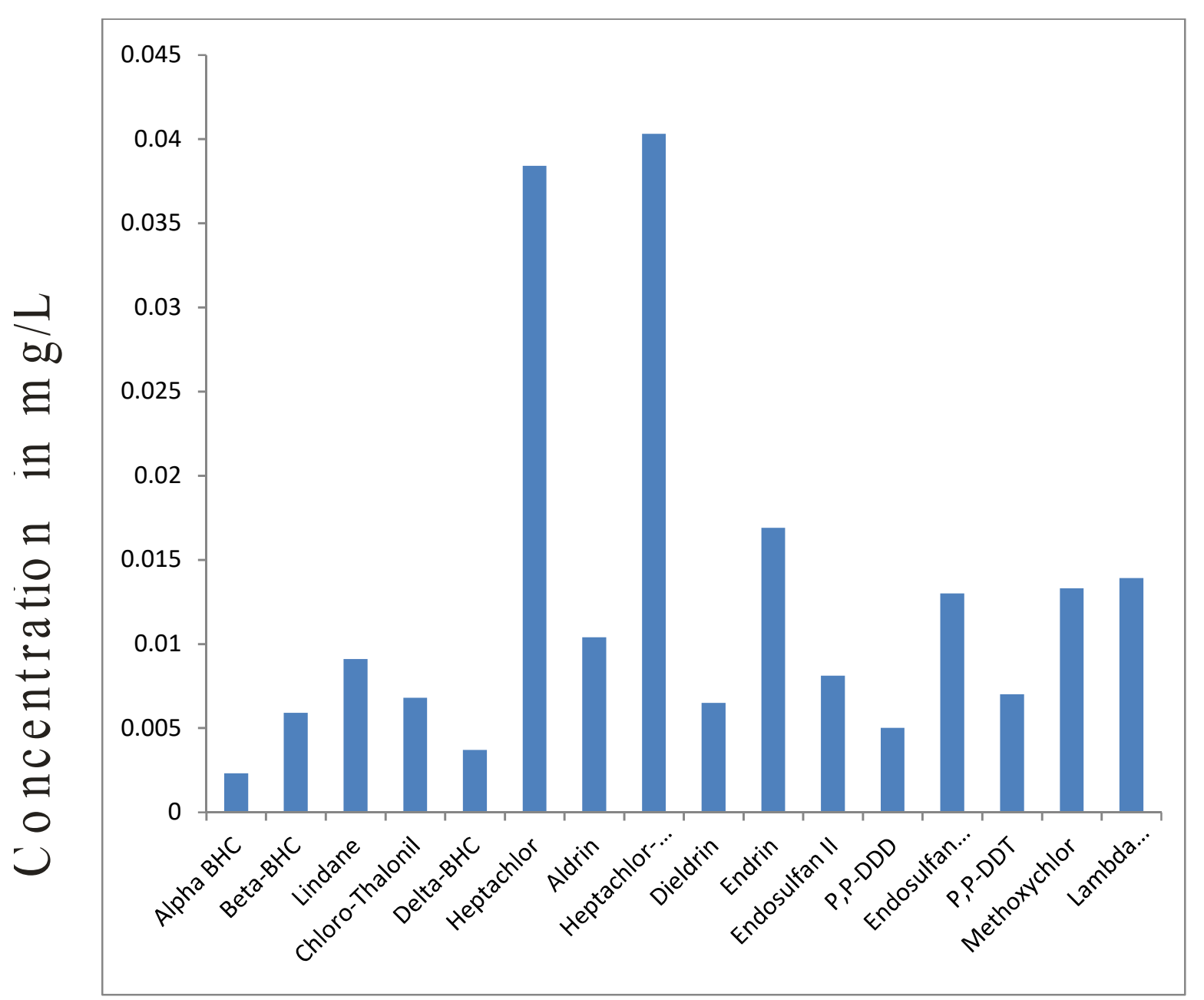

Fig. 2: Mean of Concentration of OCPs (mg/L) in Rainwater Samples Collected in Onitsha

Table 3: The concentration of PCBs $(\mathrm{mg} / \mathrm{L})$ in Rainwater Samples Collected in Onitsha.

\begin{tabular}{|c|c|c|c|c|c|c|c|c|c|}
\hline 手 & 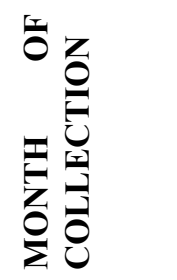 & 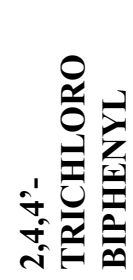 & 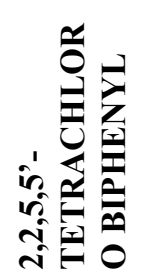 & 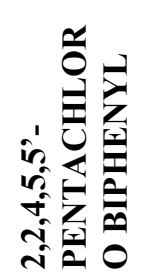 & 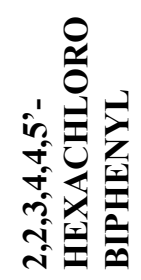 & 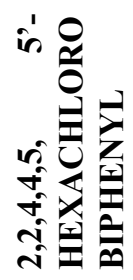 & 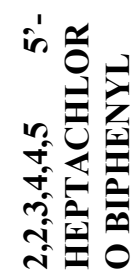 & 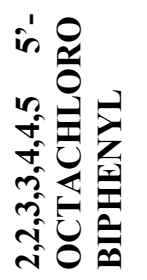 & 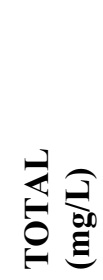 \\
\hline$\overline{\text { ON I }}$ & January & 0.027 & 0.025 & 0.033 & 0.005 & 0.010 & 0.011 & 0.014 & 0.125 \\
\hline ON 2 & February & 0.031 & 0.024 & 0.064 & 0.006 & 0.008 & 0.020 & 0.012 & 0.165 \\
\hline ON 3 & March & 0.025 & 0.019 & 0.018 & ND & ND & 0.016 & 0.014 & 0.092 \\
\hline ON 4 & April & 0.035 & 0.007 & 0.045 & 0.009 & 0.012 & 0.014 & 0.013 & 0.135 \\
\hline ON 5 & June & 0.029 & 0.006 & 0.042 & 0.004 & ND & 0.016 & 0.016 & 0.113 \\
\hline ON 6 & July & 0.036 & 0.021 & 0.037 & 0.007 & 0.014 & 0.017 & 0.016 & 0.148 \\
\hline ON 7 & August & 0.032 & 0.006 & 0.060 & 0.004 & 0.017 & 0.023 & 0.015 & 0.157 \\
\hline ON 8 & September & 0.038 & 0.024 & 0.044 & 0.011 & 0.013 & 0.014 & 0.013 & 0.157 \\
\hline ON 9 & October & 0.019 & 0.018 & 0.020 & 0.009 & ND & 0.020 & 0.016 & 0.102 \\
\hline ON 10 & December & 0.021 & 0.011 & 0.087 & 0.007 & 0.009 & 0.021 & 0.012 & 0.168 \\
\hline \multirow[t]{2}{*}{ MEAN } & & 0.029 & 0.016 & 0.045 & 0.007 & 0.012 & 0.017 & 0.014 & 0.136 \\
\hline & & 0.006 & 0.008 & 0.001 & 0.002 & 0.003 & 0.004 & 0.002 & 0.007 \\
\hline
\end{tabular}

Note: The months in which the PCBs were not detected are not included in the mean concentration. 


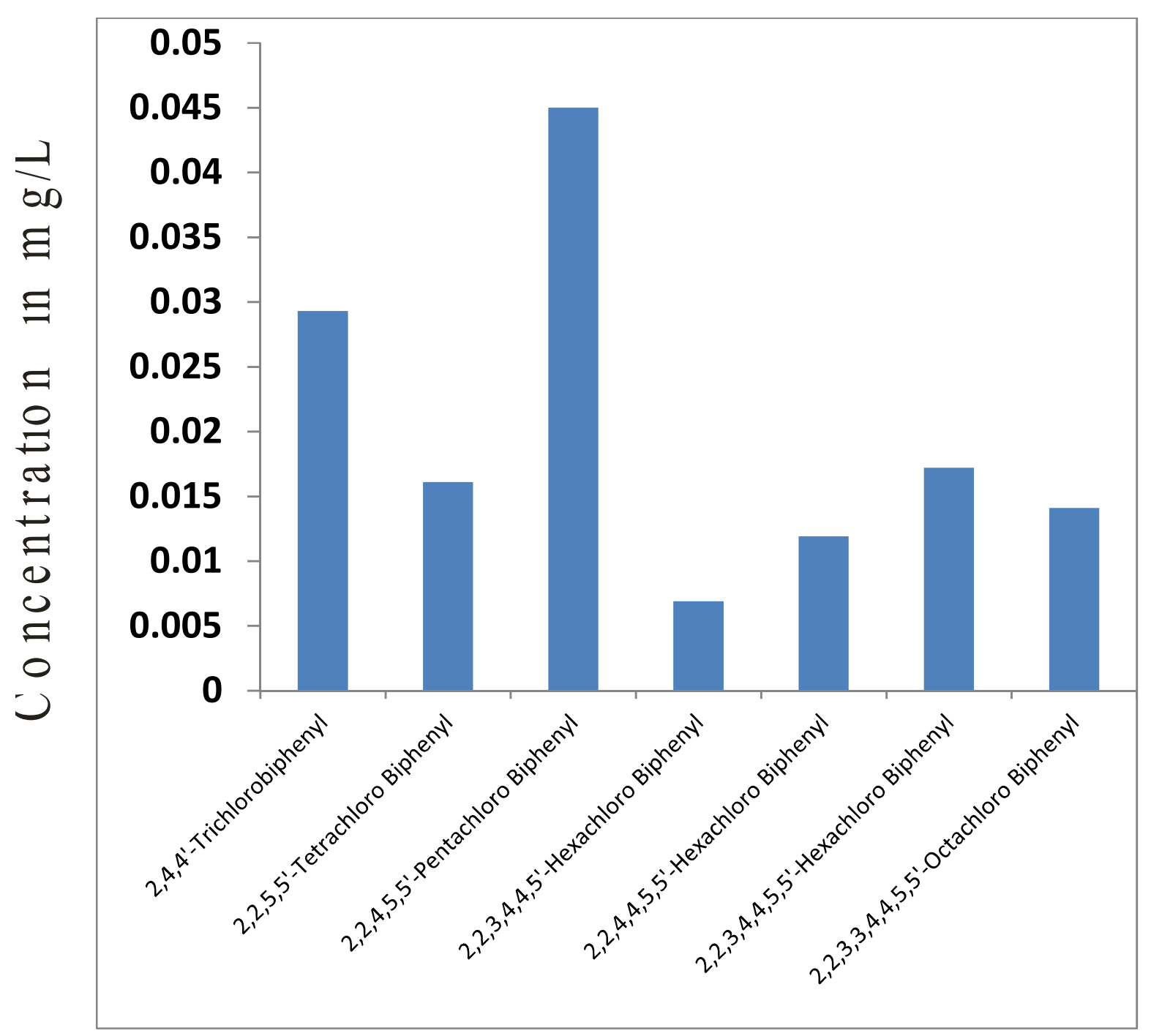

Fig.3: Mean Concentration of PCBs $(\mathrm{mg} / \mathrm{L})$ in Rainwater Samples collected in Onitsha.

\section{Discussions}

The result of the concentration of PAHs in the rainwater samples collected in Onitsha as obtained from the chromatogram is shown in Table 1. The result shows that Phenanthrene, Pyrene, Chrysene, Benzo[a]anthracene, Benzo[k]flouranthene, Benzo[b]flouranthene, Dibenzo[a,h] anthracene and Indeno[1,2,3 c-d]pyrene were not detected in the samples. Majority of the listed components have four fused benzene rings or more and often exist predominantly in the particulate phase (Baek et al., 1991; Jones et al., 1992). It has been reported that larger particles of PAHs emitted from urban source tend to settle onto the street and become part of urban runoff. This may be the reason for their absence in the samples (Butler and Schlatter, 1988). Benzo[g,h,i]perylene was detected in the rainwater sample collected in Onitsha in December and the concentration was $0.011 \mathrm{mg} / \mathrm{L}$. Since PAHs results from incomplete combustion of fossils and fuels, the presence of this component in a detectable concentration is likely due to the combustion of material peculiar to Onitsha. Also, the detection of Benzo[g,h,i]perylene in the sample even though it is a high molecular weight PAHs may be due to the fact that its atmospheric concentration was high in the month of December in Onitsha coupled with high atmospheric temperature which enhanced its solubility. The concentration is far above the acceptable limit for total PAHs in ambient quality water criteria for protection of human health which is $0.0028 \mathrm{ug} / \mathrm{L}$. A $0.510 \mathrm{mg} / \mathrm{L}$ of acenaphthylene was detected in June and $0.011 \mathrm{mg} / \mathrm{L}$ of acenaphthene was detected in August while fluorene was detected in all samples collected in Onitsha. These concentrations are above the maximum contaminant limits for potable water which is $0.0002 \mathrm{mg} / \mathrm{L}$. Fig. 1 is a chart of the Mean value of the concentrations of the individual components of PAHs in rainwater samples collected in Onitsha. It was observed that the concentration of acenaphthylene was remarkably high with an average value of $0.51 \mathrm{mg} / \mathrm{L}$. Acenaphthylene is among the low molecular mass PAHs with high vapour pressure. The phase distribution of any PAHs depends on the vapour pressure of the PAHs, the atmospheric temperature, the nature and concentration of the PAHs component (Baek et al, 1991). These 
characteristics are solubility enhancer and may have been responsible for this remarkable observation. Other components were detected in an average value range of $0.01 \mathrm{mg} / \mathrm{L}$ for anthracene to $0.033 \mathrm{mg} / \mathrm{L}$ for fluorene.

The concentrations of these PAHs were above the permissible levels when compared with the set international standard in Europe, America and other regulatory bodies. EPA's ambient quality criterion for the protection of human health in respect of PAHs is $0.0028 \mathrm{mg} / \mathrm{L}$ while EPA Maximum Contaminant Level Goal (MCLG) is $0 \mathrm{mg} / \mathrm{L}$. The WHO guideline applicable to the concentration of PAHs in drinking water is $0.2 \mathrm{~g} / \mathrm{L}(0.0002 \mathrm{mg} / \mathrm{L})$ and these values are still far less than the concentration of PAHs in the rainwater samples analyzed from Onitsha. The implication of this result is that rain water is not suitable for drinking and would have a negative health effect on both animals and humans. The fact that the PAHs could be detected in rainwater, despite their properties of low solubility showed that the air is polluted and adequate measures should be put in place to clean the atmosphere of these PAHs and therefore reduce the risk associated with exposure to human.

Table 2 showed the components of Organochlorine pesticides residue detected in the samples collected in Onitsha. The value of the components ranges between $0.002 \mathrm{mg} / \mathrm{L}$ to $0.100 \mathrm{mg} / \mathrm{L}$. The value of $0.100 \mathrm{mg} / \mathrm{L}$ was recorded for Heptachlor-epoxide in the month of April. The highest concentration of pesticide was recorded in April with a total value of $0.292 \mathrm{mg} / \mathrm{L}$ and was closely followed by a concentration of $0.272 \mathrm{mg} / \mathrm{L}$ recorded in August. The month of August is usually dry and most often termed August break as the rains drop or ceases in the month. The month with the lowest pesticide level was October with a value of $0.089 \mathrm{mg} / \mathrm{L}$. This may be due to the fact that the rains are usually heavy during this period and comes with thunderstorms which may blow away the available pesticides during this period. Fig. 2 is a chart of the mean of OCPs component residue detected in rainwater sample collected in Onitsha and it showed that heptachlor-epoxide was more prevalent followed by heptachlor.

The concentration of Organochlorine pesticide residues in the samples as compared with international guidelines are above the permissible level as the European standard for total OCPs is $0.05 \mathrm{~g} / \mathrm{L}(0.00005 \mathrm{mg} / \mathrm{L})$. The high values of these pesticides residues obtained from the analysis of the rainwater samples are markers of their air pollution in Onitsha since the atmosphere is overladen with Organochlorine pesticide residues. The effect of these pollutants to humans' results from bioaccumulation and biomagnification and is therefore essential that the concentrations of OCPs in the air are reduced to its barest minimum.

The results of the concentration of PCBs in rainwater sample collected in Onitsha (Table 3) showed that the concentration of PCBs ranges from $0.004 \mathrm{mg} / \mathrm{L}$ to $0.087 \mathrm{mg} / \mathrm{L}$. The total monthly PCBs concentration ranged from $0.092 \mathrm{mg} / \mathrm{L}$ to $0.168 \mathrm{mg} / \mathrm{L}$. The highest monthly concentration recorded in December with $0.168 \mathrm{mg} / \mathrm{L}$ may be attributed to environmental factors which enhance volatilization. The lowest monthly concentration was recorded in March. Fig. 3 which is a chart of the mean of PCBs in rainwater samples collected in Onitsha showed that $2,2^{\prime}, 4,5,5^{\prime}$-Pentachlorobiphenyl is more prevalent and is followed by $2,4,4$ '-Trichlorobiphenyls. PCBs have been widely used in the past in electrical equipment and small volumes used as fire-resistant liquid in nominally closed systems. Despite its withdrawal from use and restrictions on the production of PCBs, these compounds continue to persist in the environment. The rainwater samples had a high concentration of PCBs that are above the permissible level for potable water and therefore not suitable for use as drinking water. The EPA drinking water standard is $5 \times 10^{-4} \mathrm{ppm}(0.0005 \mathrm{mg} / \mathrm{L})$ and the Maximum Contaminant Level Goal (MCLG) is $0 \mathrm{mg} / \mathrm{L}$. The concentrations of the components of PCBs in the samples are far above the recommended standards.

\section{Conclusions}

The determination of micro-organic pollutants in rainwater samples collected from Onitsha revealed measurable amounts of PAHs, OCPs and PCBs in varied concentrations. The concentrations of the pollutants recorded in the rainwater samples are markers of their air pollution since the concentrations detected in the rainwater samples are above the international guideline. This can also be extrapolated that they are likely air pollutants in Nigeria. The likelihood of exposure of Nigerians to these toxic organic micro pollutants through breathing of air is plausible and this will require urgent intervention to mitigate their adverse health impact.

\section{References}

Baek, S., Field, R., Goldstone, M., Kirk, P., Lester, J., and Peny,R., (1991).A Review of Atmospheric Polycyclic Aromatic Hydrocarbon: Source, Fate and Behaviour. Water, Air and Soil Pollution; 60: 79-300

Beyer, A., Mackay, D., Matthies, M., Wania, F., and Webster, E., (2000). Assessing Long-Range Transport Potential of Persistent Organic Pollutants. Environmental Sciences \& Technology, 34(4): 699-703.

Bove, F.J., Slade, B.A., and Canady, R.A., (1999). Evidence of excess cancer mortality in a cohort of workers exposed to polychlorinated biphenyls. Journal of Occupational and Environmental Medicine, 41(9): 739-740.

Butler, F. S., and Schlatter, C.H., (1988). Kinetics of PCBs Elimination in Man. Chemosphere, 17: 1717 - 1726.

Chanbasha, B., Rajasekhar, B., and Hian, K., (2003). Determination of Organic Micro Pollutants in Rain Water Using Hallow Fibre Membrane/Liquid Phase Micro Extraction Combined with Gas Chromatography-Mass Spectrometry. Journal of Chromatograph A 1016(1): 11-20. 
Ezemonye, L. I. N., (2003). POPs in the environment, a Commissioned Paper Presented at the Inauguration of Edo State Chapter of Nigerian Environmental Society (NES) 3rd October 2003, Benin City.

Jones, K.C., Sandras, G., Wild, S., Burnett, V., and Johnston, A., (1992). Evidence for a Decline of PCBs and PAHs in Rural Vegetation and Air in the United Kingdom. Nature, 356: 137-140

Neff, J.M., (1984). Bioaccumulation of Organic Micro Pollutants from sediments and suspended particles by aquatic animals. Journal of Analytical Chemistry, (319): 132-136.

Ritter, L., Solomon, K.R., Forget, J., Stemeroff, M., and O’Leary, C., (2007).Persistent Organic Pollutants" United Nations Environmental Programme. Retrieved: 16 September 2007.

Tanabe, S., (1988). PCB Problems in the future: Foresight from current knowledge Environmental Pollution (50): 5-28.

U.S.EPA (2002). Performance Criteria Measurement System. US Environmental Protection Agency Washington, DC, pp: $52098-52100$. 